\title{
Job Stress and Turnover Intention: Understanding the Role of Leadership and Organizational Commitment
}

\author{
Dewiana Novitasari \\ Sekolah Tinggi Ilmu Ekonomi Insan Pembangunan, Indonesia
}

\begin{abstract}
This research aims to measure the effect of leadership style and organizational commitment on turnover intention of the automotive industry in Indonesia mediated by job stress. Data collection was carried out by simple random sampling to 253 population. The returned and valid questionnaire results were 147 samples. Data processing was using SEM method with SmartPLS 3.0 software. The results of this research are leadership style has a negative and significant effect on job stress and turnover intention. Organizational commitment has a negative and significant effect on job stress but does not significantly affect on turnover intention. Job stress has a positive and significant effect on turnover intention. Job stress was not a mediator for the relationship between leadership style, organizational commitment, and turnover intention. This novel research is proposing a model to manage turnover intention among employees of the automotive industry in Indonesia through leadership style and organizational commitment with job stress management as mediation. This research can pave the way to improve teacher readiness in facing industrial revolution 4.0.
\end{abstract}

Keywords: Job stress, leadership style, organizational commitment, turnover intention

\section{INTRODUCTION}

Human sources have big role in organizational progress and work environment. The importance of human sources makes every organization, whether it is government or company, they will recruit the best one. So that to retain the one that already recruited is the best choice rather than to make a new recruitment. If there is an employee who is really passionate in particular fields, it can be ascertained that the company will face difficulty to find the new one. To retain human sources in automotive is important. A study about why employee has a desire to resign from the organization or turnover intention should be conduct. Some experts defined that turnover intentions is a movement from employee to leave the company (Ariyabuddhiphongs \& Kahn, 2017a; Mullen et al., 2018; Park \& Pierce, 2020; Ramalho Luz et al., 2018; Wong et al., 2015). Turnover can be a resignation, move out from the organization unit, and organization employee dismissal (Abouraia \& Othman, 2017; Alkhateri et al., 2018; Ariyabuddhiphongs \& Kahn, 2017a; Mullen et al., 2018; Park \& Pierce, 2020; Ramalho Luz et al., 2018; Wong et al., 2015). Turnover is not only about an employee who move out to the other new organization, but also employee who is move to the other unit or other field that is still on the same organization (Ariyabuddhiphongs \& Kahn, 2017b). The existence of turnover intentions from employee is harmful for the organization because it can cause a negative impact for the organization itself, it can cause instability and uncertainty in work.

There are many things that cause employee has turnover intentions, one of them is leadership (Abouraia \& Othman, 2017; Ariyabuddhiphongs \& Kahn, 2017b). Leadership is process to influence other people to behave as the leader's desire (Goestjahjanti et al., 2020; Silitonga et al., 2020; Sudiyono et al., 2020). A successful leadership is when the leader succeed to reach the organizational goals without considering whether the others are compelled or not to do it (Asbari, 2019). A leader has an important role because a leader is the one who controlled and redirect the organizational goals (Hutagalung et al., 2020; Jumiran et al., 2020; Maesaroh et al., 2020; Novitasari, Asbari, et al., 2020; Novitasari, Sasono, et al., 2020; Nuryanti et al., 2020; Yuwono et al., 2020). A leader's role in organization are the intrapersonal role, a role that is informational and a role to decide the decision (Luthans, 2002). If a leader can carries out all the roles, most likely the employee will have low turnover intentions. In the intrapersonal role, a leader can gives motivation and direction when their employee are in trouble. The leader's presence can make the employee felt worth noting, so that there will be less turnover intentions. The result from a research proven that leader effectiveness negatively affected turnover intention (Park \& Pierce, 2020). The same result also mentioned that leadership has negative effect towards turnover 
intention (Ariyabuddhiphongs \& Kahn, 2017a). It means that the better leadership can reduce employee's turnover intention.

The second that cause turnover intention is commitment towards organization. Organizational commitment is a strong feeling from the employee towards organization's goals and value (Zurnali \& Nadeak, 2010). There are three dimensions of organizational commitment, 1) Affective commitment (Feeling of admiration towards organization), 2) Continuous commitment (Feeling hard to leave the organization) and 3) Normative commitment (A feeling that require to survive in the organization). Commitment towards the organization in automotive industry is supported by a good career development system. Specifically for those who are in technicians and technical support, there must be a specific career system, to improve employee's motivation to do their job better. Career development is an individual improvement to reach career plan (Sutrisno, 2015). Meanwhile career development is an individual improvement that is done to achieve particular career and an organization improvement to achieve the right working plan (Yulinasril et al., 2019). A better organizational commitment will lead to the low chance of turnover intention (Alkahtani, 2015). The same result also explained that a commitment towards organization can reduce turnover intention (Song, 2016). If employee has a commitment towards their organization, they will not have turnover intention.

Leadership and commitment towards organizations can reduce turnover intention, but leadership and commitment towards organization also affected by job stress. Job stress is a pressure that is experienced by employee (Sutardi et al., 2020). Excessive stress that felt by employee can harm their work performance to face the environment. It is often happened to employee. From the explanation above, variable that can reduce turnover intention in automotive industry employee are leadership and commitment towards organization. Thus, leadership and commitment towards organization can be a direct and indirect effect through job stress. There are many variables that related to turnover intention but so far, those three variables are the real condition from the respondent. A research that related to turnover intention is important because employee that has turnover intention in an organization can harm their company performance.

\section{LITERATURE REVIEW AND HYPOTHESIS DEVELOPMENT}

\section{A. Job Stress}

Human sources are the important roles in the organization, so every organization should manage a conducive work environmental so that the employee is free from the excessive job stress. Job stress is not only causing a bad work performance but also can cause employee to take turnover intention. (Sutardi et al., 2020). Job stress is a condition of tension that creates physical and psychic imbalances, which affect the emotions, thought processes, and conditions of employees (Rivai, 2014). Job stress is also defined as a condition of tension that affects a person's emotions, way of mind and physical condition (Siagian, 2017). Stress that is not properly addressed usually results in a person's inability to interact positively with their environment. According to Handoko (2008) stress is a condition in which an organization employee feels a strain that affects a person's thought process, emotions, and condition (Handoko, 2008). From the above understanding it can be concluded that stress is a condition felt by the employees of the organization both physically and psychically. Employees of organizations that feel stressed in their organizational environment usually feel an imbalance of physical and psychic conditions, thus impacting the thinking process, emotions, and condition of the organization's employees.

Robbins and Judge (2013) indicate of work stress into three aspects as follows:

1. Physiological indicators. This indicator can be seen from several things (a) Abdominal pain (b) Increased heart rate and shortness of breath (c) Increased blood pressure (d) Headache (e) Heart attack.

2. Psychological indicators. This indicator can be seen from several things (a) Anxiety (b) tension. (c) Boredom (d) dissatisfaction at work. (e) irritability. (f) procrastinating work.

3. Behavior indicator. This indicator can be seen from several things (a) Increased dependence on alcohol and cigarette consumption (b) Sabotage in the work. (c) Overeating or reducing unnatural eating as attractive behavior (d) Increased absenteeism rates and decreased work performance (e) Restlessness and sleep disturbances (f) Fast speech (Robbins \& Judge, 2013). 


\section{B. Leadership}

Leaders play an important role in the organization. This role is not only in the internal sphere but also on the external sphere of the organization (Asbari, Fayzhall, et al., 2020; Asbari, Purwanto, et al., 2019, 2020; Asbari, Santoso, et al., 2019; Bernarto et al., 2020; Jumiran et al., 2020). Given the importance of this role, the task of the leader in an organization is not easy. Simply put, leadership is the process for directing and influencing activities related to the duties of the organization's employees (Prameswari et al., 2020; Yanthy et al., 2020). From this defenisi it appears that leadership is a process, not a person. but at its core kempemimpin is a force that can be used to influence others to perform deeds in the desired direction (Silitonga et al., 2020; Sudiyono et al., 2020; Waruwu et al., 2020). Broadly, leadership can be interpreted as an organized effort to manage and utilize human, materil and financial resources to achieve established goals. Similarly, Nawawi (2006) states that leadership in a structural context is interpreted as a process of influencing thoughts, feelings, behaviors, and directing all facilities to achieve the goals of the organization that has been set without the participation of its group employees formulating it. While in a non-structural context, leadership is defined as the process of influencing thoughts, feelings, behaviors, and directing all facilities to achieve common goals that have been set together (Nawawi \& Hadari, 1993).

Other researchers suggest the dream is influence, if a person can increase his influence in others, they can lead more effectively (Robbins \& Judge, 2008). From some of the above, it can be concluded that leadership is an activity to influence others to work and willing to achieve common goals in an organization by utilizing all existing resources both human and non-human resources. Leadership indicators in this study will use leadership roles. If a leader has exercised his or her role in leading then it has carried out effective leadership. Leadership roles can be interpersonal, informational, and decision-making (Sutrisno, 2015). The three roles can be explained as follows:

1. Interpersonal role, One of the demands that a leader must meet is human skills. This interpersonal role consists of three forms, namely: First, as a symbol of the existence of the organization played in various activities that are legal and ceremonial such as attending various official ceremonies, fulfilling the invitation of subordinate and partner superiors. Second, as the leader responsible for motivating and giving direction to subordinates. Third, the role of liaison where a leader should be able to create a broad network by paying special attention to those who are able to do something for the organization as well as various parties who have the information needed by the organization.

2. Informational Role, Information is a crucial organising asset in its nature, because the organization's activities can be carried out efficiently and effectively without the support of up-to-date information, complete and trustworthy because it is well processed. The role consists of three forms, namely: First, a leader is a monitor of the flow of information that occurs from and into the organization. Second, the role of information divider. Information obtained by a leader other than useful in his leadership functions should also be channeled to other parties in the organization. Third, the role as a spokesperson for the organization. This role requires the ability to properly channel information to various parties outside the organization, especially when it comes to information about the plans, policies, actions, and results that have been achieved by the organization.

3. Decision making role, In this role there are three forms, namely, first as an entrepreneur. This role of a leader is expected to be able to continuously review the situation faced by the organization to achieve and find opportunities that can be utilized even though the study often demands changes in the organization. Both silencers. This role, among other things, means the willingness to assume responsibility to take corrective action if the organization faces serious disruptions that if not addressed will negatively impact the organization. The three dividing resources. This role is seen when a leader with his power or authority allocates funds and power. These include the authority to place a person in a particular position, the authority to promote a person, to demoted a person from office.

\section{Organizational Commitment}

The organization's commitment is a strong and close feeling from the organization's employees towards the goals and values of an organization (Zurnali \& Nadeak, 2010). Meanwhile, according to Luthan (2005) the organization's commitment is a strong desire to remain as an employee of a particular organization, a desire to work hard according to the organization's wishes, as well as certain beliefs and acceptance of the organization's values and objectives (Luthans, 2005). So organizational commitment means the desire of the organization's 
employees to remain employees of the organization (Robbins \& Judge, 2008). Members of organizations that are committed to their organization will tend to have high productivity. Organizational commitment can be seen from three dimensions according to Zurnali (2010) namely as follows:

1. Affective commitment (the feeling of love to the organization). Nurbiyati and Wibisono (2014) stated that the affective commitment of the organization's employees will reflect the individual strengths that will give rise to the tendency to continue working in the organization, because the employees of the organization feel in line with the company's goals and feel happy to work within the company (Nurbiyati \& Wibisono, 2016).

2. Continuous commitment (heavy feeling to leave the organization). It is stated that the employee of the organization with continuity commitment, still joins his organization because he will bear the loss if he leaves the organization or in other words the employee still remains with the organization because he needs it (Imelda et al., 2020).

3. Normative commitment (a feeling that requires staying in the organization). Hidayat (2014) stated that employees of organizations with normative commitments, still join the organization because they feel they have to do so. Normative components that develop as a result of socialization experience, depending on the extent of the employee's feelings of obligation.

\section{Turnover Intention}

Turnover intention according to Rivai (2014) turnover intention is the desire of the employee of the organization to quit the organization voluntarily or move from one place to another according to his own choice. For turnover intention organizations are very detrimental because, organizations have to process from the beginning in recruiting new organizational employees. In order to avoid turnover intention, it is necessary to make every employee of the organization have a low turnover intention. High turnover is an indication that the organization's employees are not satisfied with its current working conditions. High turnover for a high organization can be economically detrimental, as the organization has to re-spend the cost of recruiting or educating its successors. As Robbins (2006) stated, turnover can result in increased hiring, selection and training costs. In addition it can interfere with the efficiency of the management of the organization, if knowledgeable and skilled personnel leave so a replacement must be found and prepared to continue that position of responsibility. Based on the above opinion, turnover intention can be summed up the desire of individuals to leave the organization or move work to another organization either voluntarily or not in the hope of getting a more attractive job. In essence, turnover of organizational employees should be avoided because it can economically increase costs for the organization. There are several indicators of turnover intention used in this study, namely (Mobley et al., 1978):

1. Thinking of Quitting. This condition is a reflection of the organization's employees to think out of work or stay in the work environment. Starting with the dissatisfaction of the work felt by the employee, then the employee begins to think about leaving his current place of work.

2. Intention to search for alternatives. This condition is a reflection of the organization's employees looking for work in other organizations. If the employee of the organization has started to often think about getting out of his job, the employee will try to find a job outside his company that feels better.

3. Desire to quit. This condition is a reflection of the organization's employees to leave. the employee of the organization has a desire to leave if he has got a better job and will then end with the decision of the employee of the organization to stay or quit his/her job.

\section{E. Hypothetical Development}

\section{Leadership's Influence on Turnover Intention}

Leaders play an important role in the organization. This role is not only in the internal sphere but also on the external sphere of the organization. (Sutrisno, 2015). Given the importance of this role, the task of the leader in an organization is not easy. In simple terms Sutrisno (2015) leadership is a process to direct and influence activities related to the duties of the employees of the organization. Leadership indicators in this study will use leadership roles consisting of interpersonal, informational, and decision-making roles (Sutrisno, 2015). If a leader has done his function properly then it will be able to reduce turnover intention. Previous research has also shown that leadership has a significant negative influence on turnover intention (Elçi et al., 2012). This means 
that if leadership can be run properly then it can reduce turnover intention, so the hypothesis to be presented in this study is as follows:

H1: Leadership has a significant and negative effect on turnover intention

\section{The Effect of Organizational Commitment to Turnover Intention}

Robbins and Judge (2013) commitment to orgnanization means the desire of the organization's employees to remain employees of the organization. Organizations that are committed to their organization will tend to have high productivity. Organizational commitment can be seen from three dimensions according to Zurnali (2010) namely affective commitment (the feeling of love to the organization), continuous commitment (the heavy feeling of leaving the organization) and normative commitment (feelings that require enduring in the organization). If the employee of the organization has a commitment to his organization both affective commitment, continuous commitment and normative commitment then it is less likely that the organization's employees will leave the organization. The results of research conducted by Alkahtani (2015) and Song (2016) which concluded that commitment to the organization negatively affects turnover intention. From the description and results of the research that has been done before then the hypothesis that will be presented in this study is as follows:

H2: Organizational commitment has a significant and negative impact on turnover intention

\section{The Effect of Leadership on Job Stress}

Previous research has concluded that leadership has a negative influence on job stress (Elçi et al., 2012). From the previous description and the results of previous research, the hypothesis that will be presented in this study is as follows:

H3: Leadership has a significant and negative effect on job stress

\section{The Effect of Organizational Commitment on Job Stress}

Organizational commitment according to Zurnali (2010) is characterized by three things: (1) Affective commitment (love for the organization). Nurbiyati and Wibisono (2014) stated that the affective commitment of the organization's employees will reflect the individual strengths that will give rise to the tendency to continue working in the organization, because the employees of the organization feel in line with the company's goals and feel happy to work within the company. (2) Continuous commitment (a heavy feeling to leave the organization). Hidayat (2014) stated that the employee of the organization with continuity commitment, still joined his organization because he would bear the loss if he left the organization or in other words the employee still joined the organization because he needed it. (3) Normative commitment (feelings that require staying in the organization). Hidayat (2014) stated that employees of organizations with normative commitments, still join the organization because they feel they have to do so. Normative components that develop as a result of socialization experience, depending on the extent of the employee's feelings of obligation. From the previous description and the results of previous research, the hypothesis that will be presented in this study is as follows: H4: Organizational commitment has a significant and negative impact on job stress

\section{Effect of Job Stress on Turnover Intention}

Stress is a condition felt by organizational employees both physically and psychically. Employees of organizations that feel stress in their organizational environment usually feel an imbalance of physical and psychic conditions, thus impacting the thought process, emotions, and condition of the organization's employees. Stress not only negatively impacts but there is also stress that has a positive impact (Sutardi et al., 2020). So if work stress can cause employees to leave their organization then that includes negative stress. Robbins and Jugde (2013) mention that one of the factors that can cause work stress is the demands of duty. These factors include individual job design (autonomy, task diversity, automation level), working conditions and physical layout of work. The results of this study are in line with previous research that work stress is positively related to turnover intention (Mullen et al., 2018). From the previous description and the results of previous research, the hypothesis that will be presented in this study is as follows:

H5: Job stress has a significant and positive effect on turonover intention 


\section{Influence of Leadership and Organizational Commitment to Turnover Intention through Job Stress}

Job stress according to Rivai (2014) is a condition of tension that creates a physical and psychic imbalance, which affects the emotions, thought processes, and conditions of employees. The stress level of the organization's employees can be physiological such as (a) Abdominal pain (b) Increased heart rate and shortness of breath (c) Increased blood pressure (d) Headache (e) Heart attack. Stress is psychological such as (a) Anxiety (b) tension. (c) Boredom (d) dissatisfaction at work. (e) irritability. (f) delaying work and stress in the form of behavior, in the form of (a) Increased dependence on alcohol and cigarette consumption (b) Sabotage in the work. (c) Overeating or reducing unnatural eating as an attractive behavior (d) Increased absenteeism rates and decreased work performance (e) Restlessness and sleep disturbances (f) Fast speech. The results of research conducted by Mullen et al., (2018) prove that there is a positive and significant influence between work stress and turnover intention. From the theory and various previous research above, the hypothesis that will be presented in this study is as follows:

H6: Leadership has a significant and negative effect on turnover intention through job stress

H7: Organizational commitment has a significant and negative effect on turnover intention through job stress

\section{Conceptual Research Framework}

To prove the hypothesis and analyze the data from this study, the conceptual framework of this research was drawn up as in Figure 1.

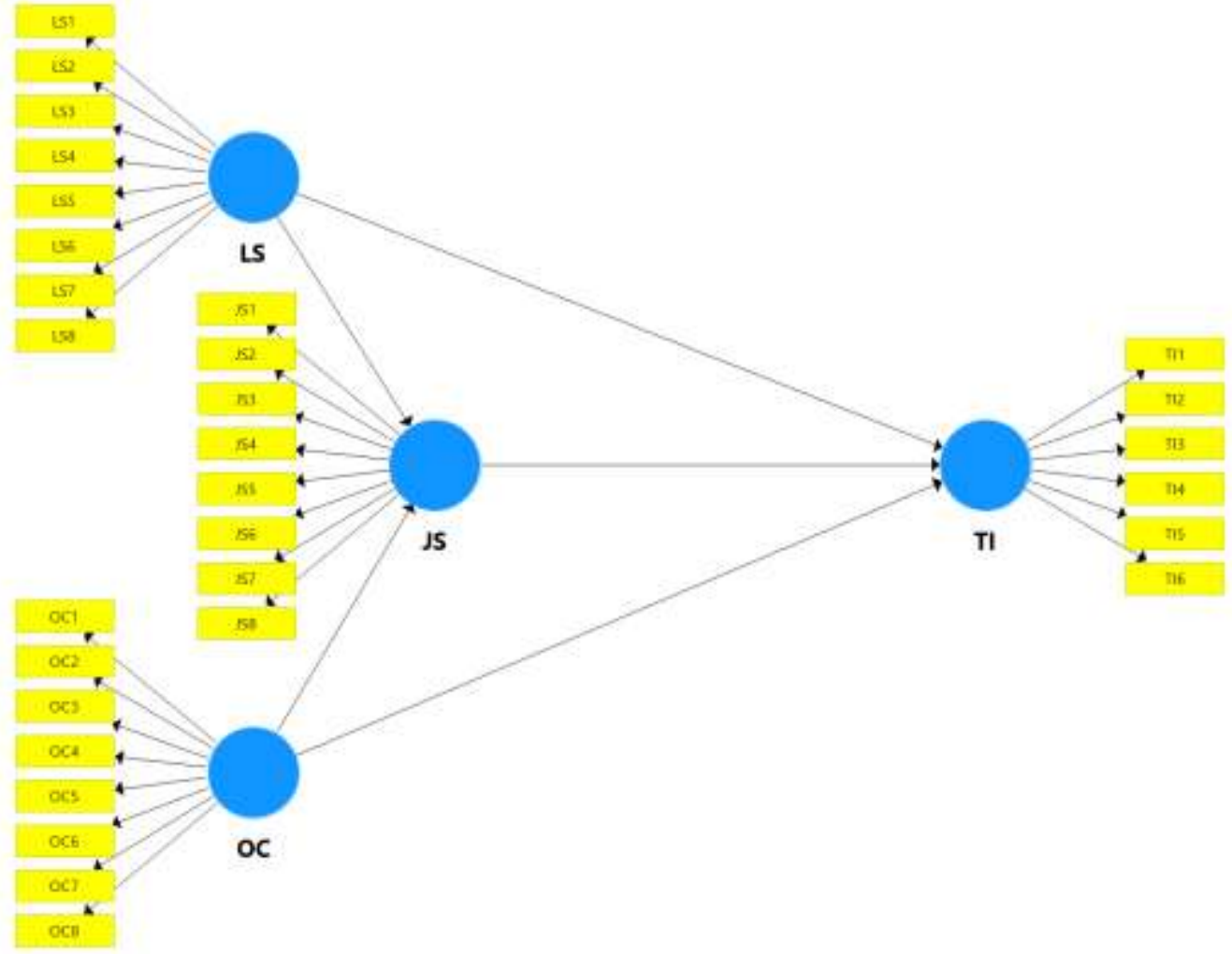

Figure 1. Research Model

\section{RESEARCH METHODS}

\section{A. Operational Definitions of Variables and Indicators}

The method used in this study is a quantitative method. Data collection is done by circulating questionnaires to all lecturers and lecturers in universities. Instruments used to measure leadership style are measured from instruments adapted from Mintzberg theory (Luthans, 2002) using 8 items (LS1-LS8). Organizational 
commitment adapted from (Allen \& Meyer, 1990) using 8 items (OC1-OC8). Job stress was adapted from (Robbins \& Judge, 2013) using 8 items (JS1-JS8). Turnover intention was adapted from (Mobley et al., 1978) using 6 items (TI1-TI6). Polls are designed to be closed except for questions/statements about the identity of respondents in the form of semi-open polls. Each closed question/statement item is given five answer options, namely: strongly agree (SS) score 5, agree (S) score 4, disagree (KS) score 3, disagree (TS) score 2, and strongly disagree (STS) score 1. The method for processing data is by PLS and using SmartPLS software version 3.0 as its tool.

\section{B. Population and Samples}

The population in this study is an employee in one of the automotive industries in Indonesia which numbered 253 people. Questionnaires are disseminated with simple random sampling techniques. The return and valid questionnaire results were 147 samples. So $58.1 \%$ of the overall population.

\section{RESEARCH RESULT AND DISCUSSION}

\section{A. Sample Descriptive}

Table 1. Sample Descriptive Information

\begin{tabular}{llll}
\hline Criteria & & Total & $\%$ \\
\hline Age & $<30$ years & 57 & $25.41 \%$ \\
& $30-40$ years & 104 & $46.60 \%$ \\
& $>40$ years & 63 & $27.99 \%$ \\
\hline Working time as employee & $<5$ years & 80 & $35.66 \%$ \\
& $5-10$ years & 109 & $48.52 \%$ \\
& $>10$ years & 35 & $15.82 \%$ \\
\hline Highest Degreee & Bachellor Degree & 20 & $5.99 \%$ \\
& Senior High School & 211 & $94.01 \%$ \\
\hline
\end{tabular}

\section{B. Validity and Reliability Test Results of Research Indicators}

The testing phase of the measurement model includes convergent validity testing, discrimination validity. While to test the reliability of the construct used cronbach's alpha value and comALite reliability. The results of the PLS analysis can be used to test the research hypothesis if all indicators in the PLS model have qualified convergent validity, deskriminan validity and reliability test.

\section{Convergent Validity Testing}

The convergent validity test is carried out by looking at the loading factor value of each indicator against its construct. In most references, a factor weight of 0.5 or more is considered to have validation strong enough to explain a latent construct (Chin, 1998; Ghozali, 2014; Hair et al., 2010). In this study the minimum limit of loading factor received was 0.5 , provided the AVE value of each construct > 0.5 (Ghozali, 2014). Based on the processing results of SmartPLS 3.0, LS5, LS7, LS8, OC5, OC8, JS3, TI4 and TI6 must be dropped from the model, in order for all indicators to have a loading factor value above 0.5 and an AVE value above 0.5. Thus, the convergent validity of this research model is already qualified. The loadings, cronbach's alpha, composite reliability and AVE values of each more construct can be seen in Figure 2 and Table 2 below: 


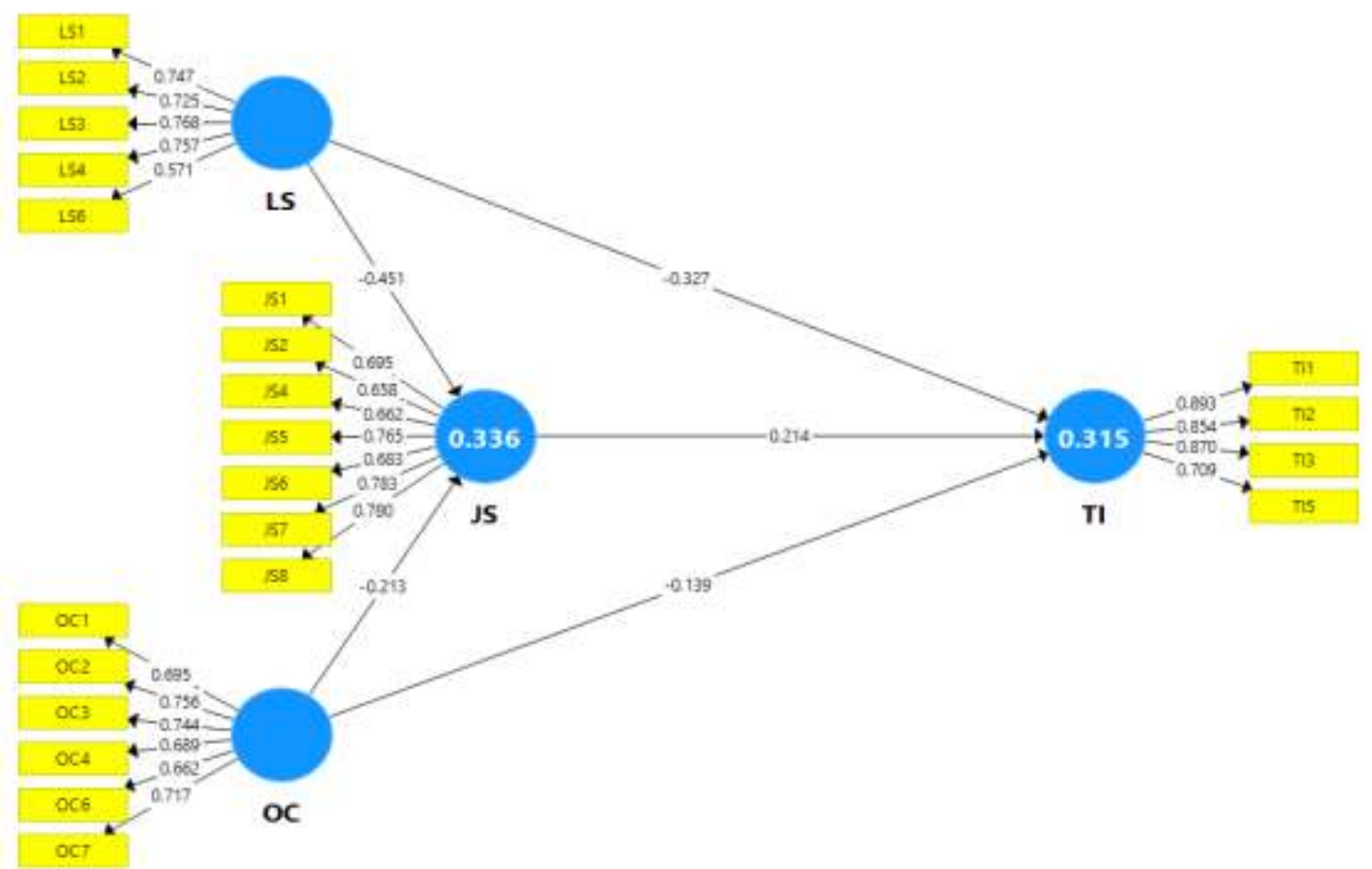

Figure 2. Research Model (Fit)

Tabel 2. Items Loadings, Cronbach's Alpha, Composite Reliability, and Average Variance Extracted (AVE)

\begin{tabular}{|c|c|c|c|c|c|}
\hline Variables & Items & Loadings & $\begin{array}{l}\text { Cronbach's } \\
\text { Alpha }\end{array}$ & $\begin{array}{l}\text { Composite } \\
\text { Reliability }\end{array}$ & AVE \\
\hline $\begin{array}{l}\text { Leadership Style } \\
\text { (LS) }\end{array}$ & $\begin{array}{l}\text { LS1 } \\
\text { LS2 } \\
\text { LS3 } \\
\text { LS4 } \\
\text { LS6 }\end{array}$ & $\begin{array}{l}0.747 \\
0.725 \\
0.768 \\
0.757 \\
0.571\end{array}$ & 0.762 & 0.840 & 0.515 \\
\hline $\begin{array}{l}\text { Organizational } \\
\text { Commitment } \\
\text { (OC) }\end{array}$ & $\begin{array}{l}\text { OC1 } \\
\text { OC2 } \\
\text { OC3 } \\
\text { OC4 } \\
\text { OC6 } \\
\text { OC7 }\end{array}$ & $\begin{array}{l}0.695 \\
0.756 \\
0.744 \\
0.689 \\
0.662 \\
0.717\end{array}$ & 0.820 & 0.860 & 0.506 \\
\hline $\begin{array}{l}\text { Job Stress } \\
\text { (JS) }\end{array}$ & $\begin{array}{l}\text { JS1 } \\
\text { JS2 } \\
\text { JS4 } \\
\text { JS5 } \\
\text { JS6 } \\
\text { JS7 } \\
\text { JS8 }\end{array}$ & $\begin{array}{l}0.695 \\
0.658 \\
0.662 \\
0.765 \\
0.683 \\
0.783 \\
0.780\end{array}$ & 0.846 & 0.882 & 0.518 \\
\hline $\begin{array}{l}\text { Turnover Intention } \\
\text { (TI) }\end{array}$ & $\begin{array}{l}\text { TI1 } \\
\text { TI2 } \\
\text { TI3 } \\
\text { TI5 }\end{array}$ & $\begin{array}{l}0.753 \\
0.821 \\
0.828 \\
0.663\end{array}$ & 0.852 & 0.901 & 0.697 \\
\hline
\end{tabular}




\section{Deskriminan Validity Testing}

Discriminant validity is performed to ensure that each concept of each latent variable is different from other latent variables. Models have good discriminant validity if the ave squared value of each exogenous construct (value on diagonal) exceeds the correlation between the construct and the other construct (value below diagonal) (Ghozali, 2014). The results of the discriminant validity test using ave squared values, i.e. by looking at the Fornell-Larcker Criterion Value obtained as mentioned in Table 3. The results of the deskriminan validity test in table 3 show that the entire construct already has an AVE square root value above the correlation value with other latent constructs (through the Fornell-Larcker criteria) so it can be concluded that the model has met the validity of the decriminal (Fornell \&amp; Larcker, 1981).

\section{Construct Reliability Testing}

Construct reliability can be assessed from cronbach's alpha and comALite reliability values from each construct. The recommended comALite reliability and cronbach's alpha values are more than 0.7 (Ghozali, 2014). The reliability test results in table 2 above show that the entire construct already has a composite reliability value and Cronbach's alpha is greater than 0.7 ()0.7). In conclusion, the entire construct has fulfilled the required reliability.

\section{Hypothesis Testing}

Hypothesis testing in PLS is also referred to as the inner model test. These tests include tests of the significance of direct and indirect influences as well as measurements of the large influence of exogenous variables on endogenous variables. To know the effect of authentic leadership on the performance of lecturers with variable mediation of lecturer engagement requires a direct and indirect influence test. Influence tests are conducted using t-statistical tests in a partial least squared (PLS) analysis model using the help of SmartPLS 3.0 software. With boothstrapping techniques, R Square values and significance test scores are obtained as shown in the table below:

Tabel 3. Discriminant Validity

\begin{tabular}{lllll}
\hline Variables & JS & LS & OC & TI \\
\hline JS & $\mathbf{0 . 7 2 0}$ & & & \\
LS & -0.548 & $\mathbf{0 . 7 1 7}$ & & \\
OC & -0.418 & 0.454 & $\mathbf{0 . 7 1 1}$ & $\mathbf{0 . 8 3 5}$ \\
TI & 0.451 & -0.507 & -0.377 & \\
\hline
\end{tabular}

Table 4. R Square Value

\begin{tabular}{lll}
\hline & R Square & R Square Adjusted \\
\hline JS & 0.336 & 0.327 \\
TI & 0.315 & 0.301 \\
\hline
\end{tabular}

Table 5. Hypotheses Testing

\begin{tabular}{lllllll}
\hline Hypotheses & Relationship & Beta & SE & T Statistics & P-Values & Decision \\
\hline H1 & LS -> TI & -0.327 & 0.127 & 2.582 & 0.010 & Supported \\
H2 & OC -> TI & -0.139 & 0.098 & 1.429 & 0.154 & Not Supported \\
H3 & LS -> JS & -0.451 & 0.084 & 5.351 & 0.000 & Supported \\
H4 & OC -> JS & -0.213 & 0.078 & 2.735 & 0.006 & Supported \\
H5 & JS -> TI & 0.214 & 0.108 & 1.972 & 0.049 & Supported \\
H6 & LS -> JS -> TI & -0.097 & 0.055 & 1.754 & 0.080 & Not Supported \\
H7 & OC -> JS -> TI & -0.046 & 0.030 & 1.520 & 0.129 & Not Supported \\
\hline
\end{tabular}

Based on Table 4 above, the R Square job stress (JS) value of 0.336 means that the job stress (JS) variable is able to be explained by leadership style (LS) and organizational commitment (OC) variables of 33.6\%, while the remaining $66.4 \%$ is explained by other variables not discussed in this study. Meanwhile, the R Square turnover intention (IT) value of 0.315 means that the turnover intention (TI) variable can be explained by variable stress 
(JS) leadership style (LS) and organizational commitment (OC) of 31.5\%, while the remaining 69.5\% is explained by other variables not discussed in this study. While Table 5 displays T Statistics and P-Values that show the influence between the research variables mentioned.

\section{Discussion}

\section{The Effect of Leadership on Turnover Intention}

From the hypothetical results in Table 5 it can be noted that there is a significant negative influence of leadership style on turnover intention. This is evidenced by the level of sig. $0.000(\mathrm{P}<0.05)$. The resulting coefficient is negative -0.327 . This negative coefficient indicates if the better leadership then the turnover of employee intentions will be smaller. Likewise, the results of this study support the results of previous research conducted by Nyoman and Deniartha (2016) proving that leadership has a significant negative influence on turnover intention (Nyoman \& Deniartha, 2016). 2015). Looking at the importance of this role, the task of the leader in an organization is not easy. Sutrisno, 2015). If a leader has done his or her function properly it will be able to reduce turnover intention. The resulting coefficient is negative -0.139 . This negative coefficient shows that if the better the employee's commitment then the turnover intention is smaller. The results of research conducted by Alkahtani (2015), Song (2016), Nyoman and Deniartha (2016) concluded that commitment to the organization negatively affects turnover intention. Robbins and Judge (2013) commitment to orgnanization means the desire of the organization's employees to remain employees of the organization. Organizations that are committed to their organization will tend to have high productivity. Organizational commitment can be seen from three dimensions according to Zurnali (2010) namely affective commitment (the feeling of love to the organization), continuous commitment (the heavy feeling of leaving the organization) and normative commitment (feelings that require enduring in the organization). If an employee of the organization has a commitment to his organization both affective commitment, continuous commitment and normative commitment then it is less likely that the organization's employees will leave the organization.

\section{The Effect of Organizational Commitment to Turnover Intention}

Hypothetical test results prove that there is a negative but insignificant influence between the organization's commitment and turnover intention. This is evidenced by the level of sig. $0.154(\mathrm{P}>0.05)$. The resulting coefficient is negative -0.139 . This negative coefficient shows that if the better the employee's commitment then the turnover intention is smaller. The results of research conducted by Alkahtani (2015), Song (2016), Nyoman and Deniartha (2016) concluded that commitment to the organization negatively affects turnover intention. Robbins and Judge (2013) commitment to orgnanization means the desire of the organization's employees to remain employees of the organization. Organizations that are committed to their organization will tend to have high productivity. Organizational commitment can be seen from three dimensions according to Zurnali (2010) namely affective commitment (the feeling of love to the organization), continuous commitment (the heavy feeling of leaving the organization) and normative commitment (feelings that require enduring in the organization). If an employee of the organization has a commitment to his organization both affective commitment, continuous commitment and normative commitment then it is less likely that the organization's employees will leave the organization.

\section{The Effect of Leadership on Work Stress}

Based on the test results it is known that the leadership variable has a t-statistic value of 5,351 with sig.t of 0.000 ( $\mathrm{p}<0.05)$. This means leadership variables are shown to have a significant and negative influence on work stress. The results of this study support research conducted by (Elçi et al., 2012) which concluded that leadership has a negative influence on work stress. These results show if the leader can perform his or her role well. Sutrisno (2015) mentioned that one of the roles of leader is a decision-making role. In this role there are three forms, namely, first as an entrepreneur. This role of a leader is expected to be able to continuously review the situation faced by the organization to achieve and find opportunities that can be utilized even though the study often demands changes in the organization. Both silencers. This role, among other things, means the willingness to assume responsibility to take corrective action if the organization faces serious disruptions that if not addressed will negatively impact the organization. The three dividing resources and resources. This role is seen when a leader with his power or authority allocates funds and power. These include the authority to place a person in a particular position, the authority to promote a person, to demoted a person from office. So the implementation of the role of leaders in decision making by itself can reduce the stress level of employee work. 
As a silencer of the emerging problem, a leader is willing to assume the responsibility to take corrective action if the organization faces serious disruptions that otherwise will negatively impact the organization. Thus the level of work stress felt by employees can be reduced if the leader has done his or her role well.

\section{The Effect of Organizational Commitment on Work Stress}

Based on the test results it is known that the organization's commitment variable has a t-count value of 2,735 with a sig.t of $0.006(\mathrm{p}<0.05)$. This means that organizational commitment variables are shown to have a significant and negative influence on work stress. By looking at aspects of the commitment to the organization above shows if employees who are committed to their organization can reduce the level of work stress. This negative influence indicates that if the higher the commitment of employees to have a high commitment to their organization then it can reduce work stress. Thus the establishment of employees who are committed to their organization becomes very important to be done by the organization. This is because commitment to the organization can reduce work stress.

\section{The Effect of Job Stress on Turnover Intention}

Based on the results of the hypothesis test it is known that the working stress variable has a t-count value of 1,972 with sig.t of 0.049 ( $p<0.05$ ). This means work stress variables are shown to have a significant and positive influence on turnover intentions. Results show that if the higher the stress level in employees then the likelihood of the level of desire to exit is also higher. Stress is a condition felt by organizational employees both physically and psychically. Employees of organizations that feel setres in their organizational environment usually feel an imbalance of physical and psychic conditions, thus impacting the thought process, emotions, and condition of the organization's employees. Stress according to Gaol (2016) not only negatively impacts but there is also stress that has a positive impact. So if work stress can cause employees to leave their organization then that includes negative stress. Robbins and Jugde (2013) mention that one of the factors that can cause work stress is the demands of duty. These factors include individual job design (autonomy, task diversity, automation level), working conditions and physical layout of work. The results of this study are in line with research conducted by Mosadeghrad (2013), work stress is positively related to turnover intention. The results of this study show that work stress can be one of the causes of employees having turnover intentions.

\section{The Effect of Leadership on Turnover Intention Through Work Stress}

The data analysis showed that the direct influence between leadership on turnover intention had a coefficient of minus -0.327 , while the indirect effect of work stress had a coefficient of minus -0.097 which is the result of the coefficient of leadership's influence on work stress (-0.451) and work stress coefficient on turnover intention of (0.214). From this result, it can be known that the direct coefficient has a greater coefficient value than indirect influence, so the influence between leadership on turnover intention is a direct influence that is, without going through work stress. The results of this study provide information if turnover intention in the organization will be greater while the stress level is large or high. High stress will have an impact on the high turnover intention. Although leadership is good, but when company employees feel a high level of stress then there is the potential for turnover intentions to increase.

\section{The Effect of Organizational Commitment on Turnover Intention Through Work Stress}

The results of the data analysis in Table 5 obtained the result that the direct influence between the organization's commitment to Turnover Intention has a coefficient of minus -0.139 , while the indirect influence of work stress has a coefficient of minus -0.046 which is the result of the coefficient of the organization's commitment to work stress $(-0.213)$ and the coefficient of work stress against turnover intention of (0.214). From these results it can be known that the direct coefficient has a greater coefficient value than indirect influence, so the influence between the organization's commitment to turnover intention is a direct influence that is, not through work stress. The results of this study provide information if the turnover intention will be greater while the stress level is large or high. High stress will have an impact on the high turnover intention. Although employees have a high commitment to their organization, but when employees feel a high level of stress then there is the potential for turnover intention to increase. 


\section{CONCLUSION AND SUGGESTION}

\section{A. Conclusion}

This study contributes to the scientific literature on turnover intention by developing and validating research models that describe the role of leadership style, organizational commitment and job stress in the automotive industry in Indonesia. This study can be useful for company management to strategize in developing a competent workforce, committing well with the organization and providing a competitive edge. Corporate organizations need to always look for ways that existing employees can manage and manage work stress by getting positive support from leaders and organizations. Positive Results in the form of leadership style support and organizational commitment should provide sufficient encouragement to minimize work stress levels. This study examines only a few variables, future research may expand the number of variables in this model. Additional variables such as awards and recognition, job satisfaction, etc. can also be considered to be explained in future research. This research is limited to the context of the automotive industry, studies in other types of industries can be conducted to see if there are variations in results and other conclusions.

\section{B. Suggestion}

From the results of the study and conclusions then the advice submitted is as follows: First, work stress is the main cause of turnover intention, for that improvement in terms of leadership and organizational commitment will not be able to reduce turnover intention if work stress is not immediately ed. Therefore, the necessary thing in an effort to reduce turnover intention is to reduce the level of work stress. Second, the work stress variables in this study lead more to work stress that negatively impacts, so for further research can use work stress that has a positive impact.

\section{REFERENCES}

[1] Abouraia, M. K., \& Othman, S. M. (2017). Transformational Leadership, Job Satisfaction, Organizational Commitment, and Turnover Intentions: The Direct Effects among Bank Representatives. American Journal of Industrial and Business Management, 07(04), 404-423. https://doi.org/10.4236/ajibm.2017.74029

[2] Alkahtani, A. H. (2015). Investigating factors that influence employees' turnover intention: A review of existing empirical works. International Journal of Business and Management, 10(12), 152.

[3] Alkhateri, A. S., Khalifa, G. S. A., \& Ameen, A. (2018). The Impact of Perceived Supervisor Support on Employees Turnover Intention: The Mediating Role of Job Satisfaction and Affective Organizational Commitment Total Quality Management Practices View project The Impact of Emotional Intelligence on Work Life Ba. 12(December), 477-492. https://doi.org/10.3923/ibm.2018.477.492

[4] Allen, N. J., \& Meyer, J. P. (1990). The measurement and antecedents of affective, continuance and normative commitment to the organization. Journal of Occupational Psychology, 63, 1-18. https://doi.org/https://doi.org/10.1111/j.2044-8325.1990.tb00506.x

[5] Ariyabuddhiphongs, V., \& Kahn, S. I. (2017a). Transformational leadership and turnover intention $\square$ : The mediating effects of rust and job performance on café employees in Thailand. Journal of Human Resources in Hospitality \& Tourism, 16(2), 215-233. https://doi.org/10.1080/15332845.2016.1202730

[6] Ariyabuddhiphongs, V., \& Kahn, S. I. (2017b). Transformational leadership and turnover intention: The mediating effects of trust and job performance on café employees in Thailand. Journal of Human Resources in Hospitality and Tourism, 16(2), 215-233. https://doi.org/10.1080/15332845.2016.1202730

[7] Asbari, M. (2015). Fokus Satu Hebat. Penerbit Dapur Buku.

[8] Asbari, M. (2018). Ayah tanpa Wajah. Penerbit Tosca.

[9] Asbari, M. (2019). Pengaruh kepemimpinan transformasional dan iklim organisasi terhadap kinerja dosen. JOCE IP, 13(2), 172186. http://jurnal.ipem.ac.id/index.php/joce-ip/article/view/187

[10] Asbari, M., Fayzhall, M., Goestjahjanti, F. S., Winanti, Yuwono, T., Hutagalung, D., Basuki, S., Maesaroh, S., Mustofa, Chidir, G., Yani, A., \& Purwanto, A. (2020). Peran Kepemimpinan Transformasional Dan Organisasi Pembelajaran Terhadap Kapasitas Inovasi Sekolah. EduPsyCouns: Journal of Education, Psychology and Counseling, 2(1), 6724-6748. https://ummaspul.ejournal.id/Edupsycouns/article/view/421

[11] Asbari, M., Purwanto, A., \& Budi, P. (2020). Pengaruh Iklim Organisasi dan Kepemimpinan Transformasional Terhadap Produktivitas Kerja Inovatif Pada Industri Manufaktur di Pati Jawa Tengah . Jurnal Produktivitas, 7(1), 62-69. https://doi.org/http://dx.doi.org/10.29406/jpr.v7i1.1797

[12] Asbari, M., Purwanto, A., \& Santoso, P. B. (2019). Influence of Leadership, Motivation, Competence, Commitment and Culture on ISO 9001:2015 Performance in Packaging Industry. Scholars Journal of Economics, Business and Management, 6(12), 577-582. 
https://doi.org/10.36347/sjebm.2019.v06i12.005

[13] Asbari, M., Santoso, P. B., \& Purwanto, A. (2019). Pengaruh Kepemimpinan dan Budaya Organisasi Terhadap Perilaku Kerja Inovatif pada Industri 4.0. Jim UPB, 8(1), 7-15. https://doi.org/ttps://doi.org/10.33884/jimupb.v8i1.1562

[14] Bernarto, I., Bachtiar, D., Sudibjo, N., Suryawan, I. N., Purwanto, A., \& Asbari, M. (2020). Effect of transformational leadership, perceived organizational support, job satisfaction toward life satisfaction: Evidences from indonesian teachers. International Journal of Advanced Science and Technology, 29(3), 5495-5503. http://sersc.org/journals/index.php/IJAST/article/view/6057

[15] Chin, W. (1998). The Partial Least Squares Approach to Structural Equation Modeling (E. Modern Methods for Business Research, In: G. A. Marcoulides (ed.)). Lawrence Erlbaum Associates Publisher.

[16] Elçi, M., Şener, İ., Aksoy, S., \& Alpkan, L. (2012). The impact of ethical leadership and leadership effectiveness on employees turnover intention: The mediating role of work related stress. Procedia-Social and Behavioral Sciences, 58, $289-297$.

[17] Fornell, C., \& Larcker, D. F. (1981). Evaluating Structural Equation Models with Unobservable Variables and Measurement Error. Journal of Marketing Research, 18(1), 39. https://doi.org/10.2307/3151312

[18] Ghozali, I. (2014). Structural Equation Modeling, Metode Alternatif dengan Partial Least Square (PLS) (4th ed.). Badan Penerbit Universitas Diponegoro.

[19] Goestjahjanti, S. F., Novitasari, D., Hutagalung, D., Asbari, M., \& Supono, J. (2020). Impact of Talent Management, Authentic Leadership and Employee Engagement on Job Satisfaction: Evidence From South East Asian Industries. Journal of Critical Reviews, 7(19), 67-88. http://www.jcreview.com/?mno=101983

[20] Hair, J. F., Black, W. C., Babin, B. J., \& Anderson, R. E. (2010). Multivariate Data Analysis (7th ed.). Pearson Prentice Hall.

[21] Handoko, T. H. (2008). Manajemen Personalia dan Sumber Daya. Manusia (Edisi 2). Yogyakarta: BPFE.

[22] Hutagalung, D., Asbari, M., Fayzhall, M., Ariyanto, E., Agistiawati, E., Sudiyono, R. N., Waruwu, H., Goestjahjanti, F. S., Winanti, \& Yuwono, T. (2020). Peran Religiusitas, Kepemimpinan Transformasional, Kepuasan Kerja dan Mediasi Organizational Citizenship Behavior terhadap Kinerja Guru. EduPsyCouns: Journal of Education, Psychology and Counseling, 2(1), 311-326. https://ummaspul.e-journal.id/Edupsycouns/article/view/483

[23] Imelda, D., Asbari, M., Purwanto, A., Sestri Goestjahjanti, F., \& Mustikasiwi, A. (2020). The Effect of Fairness of Performance Appraisal, Job Satisfaction and Commitment on Employees' Performance: Evidence from Indonesian Automotive Industry. International Journal of Advanced Science and Technology, 29(4), 2383-2396. https://doi.org/http://sersc.org/journals/index.php/IJAST/article/view/20519

[24] Jumiran, Novitasari, D., Nugroho, Y. A., Sutardi, D., Sasono, I., \& Asbari, M. (2020). Pengaruh Dimensi Kepemimpinan Transformasional terhadap Kepuasan Kerja dan Komitmen Organisasional: Studi Kasus pada Dosen Perguruan Tinggi Swasta. EduPsyCouns: Journal of Education, Psychology and Counseling, 2(1), 600-621. https://ummaspul.ejournal.id/Edupsycouns/article/view/555

[25] Luthans, F. (2002). Organizations Behavior. McGraw Hill International: John E. Biernat.

[26] Luthans, F. (2005). Perilaku Organisasi (11th ed.). Penerbit ANDI

[27] Maesaroh, S., Asbari, M., Hutagalung, D., Agistiawati, E., Basuki, S., Radita, F. R., Nurasiah, Yulia, Y., Singgih, E., \& Chidir, G. (2020). Pengaruh Religiusitas dan Kepemimpinan Transformasional terhadap Kinerja Guru melalui Mediasi Organizational Citizenship Behavior. EduPsyCouns: Journal of Education, Psychology and Counseling, 2(1), 276-290. https://ummaspul.ejournal.id/Edupsycouns/article/view/473

[28] Mobley, W. H., Horner, S. O., \& Hollingsworth, A. T. (1978). An evaluation of precursors of hospital employee turnover. Journal of Applied Psychology, 63(4), 408-414. https://doi.org/10.1037/0021-9010.63.4.408

[29] Mullen, P. R., Malone, A., Denney, A., \& Dietz, S. S. (2018). Job Stress, Burnout, Job Satisfaction, and Turnover Intention Among Student Affairs Professionals. College Student Affairs Journal, 36(1), 94-108. https://doi.org/https://doi.org/10.1353/csj.2018.0006

[30] Nawawi, H., \& Hadari, M. M. (1993). Kepemimpinan yang efektif. Gadjah Mada Press.

[31] Novitasari, D., Asbari, M., Sutardi, D., GazalI, \& Silitonga, N. (2020). Mempertahankan Kinerja Karyawan di Masa Pandemi Covid-19: Analisis Kesiapan untuk Berubah dan Efektivitas Kepemimpinan Transformasional. Value: Jurnal Manajemen Dan Akuntansi, 15(2), 22-37. https://doi.org/https://doi.org/10.32534/jv.v15i2.1152

[32] Novitasari, D., Sasono, I., Santoso, J., Sudiyono, R. N., \& Asbari, M. (2020). Pengaruh Kesiapan untuk Berubah pada Karyawan Manufaktur: Analisis Praktik Kepemimpinan di Masa Pandemi Covid-19. JUMBO (Jurnal Manajemen , Bisnis Dan Organisasi), 4(1), 175-188. https://doi.org/http://dx.doi.org/10.33772/jumbo.v4i1.13260

[33] Nurbiyati, T., \& Wibisono, K. (2016). Analisis pengaruh komitmen afektif, kontinyu dan normatif terhadap kinerja dengan disiplin kerja sebagai variabel intervening. Jurnal Kajian Bisnis, 22(1).

[34] Nuryanti, Y., Novitasari, D., Nugroho, Y. A., Fauji, A., Gazali, \& Asbari, M. (2020). Meningkatkan Komitmen Organisasional Dosen: Analisis Pengaruh Kepemimpinan Perguruan Tinggi dan Kepuasan Intrinsik \& Ekstrinsik Dosen. EduPsyCouns: Journal of Education, Psychology and Counseling, 2(1), 561-581. https://ummaspul.e-journal.id/Edupsycouns/article/view/551 
[35] Nyoman, S. N., \& Deniartha, I. (2016). Peran Kepemimpinan, Komitmen Organisasi, Trunover Intention, Kepuasan Kerja dan Kinerja Karyawan LPD Desa Adat Tanjung Benoa-Badung. Jurnal Manajemen \& Bisnis, 13(3), 120-130.

[36] Park, T., \& Pierce, B. (2020). Impacts of transformational leadership on turnover intention of child welfare workers. Children and Youth Services Review, 108, 104624. https://doi.org/10.1016/j.childyouth.2019.104624

[37] Prameswari, M., Asbari, M., Purwanto, A., Ong, F., Kusumaningsih, S. W., Mustikasiwi, A., Chidir, G., Winanti, \& Sopa, A. (2020). The impacts of leadership and organizational culture on performance in indonesian public health: The mediating effects of innovative work behavior. International Journal of Control and Automation, 13(2), $216-227$. http://sersc.org/journals/index.php/IJCA/article/view/7630

[38] Ramalho Luz, C. M. D., Luiz de Paula, S., \& de Oliveira, L. M. B. (2018). Organizational commitment, job satisfaction and their possible influences on intent to turnover. Revista de Gestão, 25(1), 84-101. https://doi.org/10.1108/rege-12-2017-008

[39] Rivai, V. (2014). Manajemen Sumber Daya Manusia untuk Perusahaan, Edisi ke 6, PT. Raja Grafindo Persada, Depok, 16956.

[40] Robbins, S. P., \& Judge, T. A. (2008). Organizational Behavior. Prentise Hall.

[41] Robbins, S. P., \& Judge, T. A. (2013). Organizational Behavior. Pearson Education Inc.

[42] Siagian, S. P. (2017). Manajemen sumber daya manusia. Bumi Aksara.

[43] Silitonga, N., Novitasari, D., Sutardi, D., Sopa, A., Asbari, M., Yulia, Y., Supono, J., \& Fauji, A. (2020). The Relationship of Transformational Leadership, Organizational Justice and Organizational Commitment: a Mediation Effect of Job Satisfaction. Journal of Critical Reviews, 7(19), 89-108. http://www.jcreview.com/?mno=101999

[44] Song, L. (2016). A study of factors influencing turnover Intention of King Power group at downtown area in Bangkok, Thailand. International Review of Research in Emerging Markets and the Global Economy (IRREM) An Online International Research Journal (ISSN: 2311-3200), 2(3).

[45] Sudiyono, R. N., Fikri, M. A. A., Asbari, M., Suroso, Nugroho, Y. A., \& Singgih, E. (2020). The Role of Employee Engagement in the Relationship between Authentic Leadership, Talent Management and Job Satisfaction. International Journal of Advanced Science and Technology, 29(5), 11809-11836. http://sersc.org/journals/index.php/IJAST/article/view/25377

[46] Sutardi, D., Novitasari, D., Asbari, M., Silitonga, N., Nugroho, Y. A., Hutagalung, D., Mustofa, Chidir, G., Basuki, S., \& Yuwono, T. (2020). Pengaruh Work-Family Conflict, Stres Kerja dan Social Support terhadap Kepuasan Kerja: Studi Kasus pada Guru Wanita di Tangerang. EduPsyCouns: Journal of Education, Psychology and Counseling, 2(1), 482-498. https://ummaspul.ejournal.id/Edupsycouns/article/view/513

[47] Sutrisno, E. (2015). Manajemen Sumber Daya Manusia (Cetakan ke tujuh). Jakarta: Kencana Prenada Media Group.

[48] Waruwu, H., Asbari, M., Purwanto, A., Nugroho, Y. A., Fikri, M. A. A., Fauji, A., Shobihi, A. W. I., Hulu, P., Sudiyono, R. N., Agistiawati, E., \& Dewi, W. R. (2020). The Role of Transformational Leadership, Organizational Learning and Structure on Innovation Capacity: Evidence from Indonesian Private Schools. EduPsyCouns: Journal of Education, Psychology and Counseling, 2(1), 378-397. https://ummaspul.e-journal.id/Edupsycouns/article/view/499

[49] Wong, Y., Wong, Y.-W., \& Wong, C. (2015). An integrative model of turnover intention: Antecedents and their effects on employee performance in Chinese joint ventures. Journal of Chinese Human Resource Management, 6(1), 71-90. https://doi.org/http://dx.doi.org/10.1108/JCHRM-06-2014-0015

[50] Yanthy, E., Purwanto, A., Pramono, R., Cahyono, Y., \& Asbari, M. (2020). Pengaruh Gaya Kepemimpinan Transformasional dan Tranksaksional Terhadap Kinerja Sistem Jaminan Halal HAS 23000. Jurnal Bisnis Dan Manajemen Islam, 8(1), $131-153$. https://doi.org/http://dx.doi.org/10.21043/bisnis.v8i1.7045

[51] Yulinasril, Y., Wardi, Y., \& Masdupi, E. (2019). The Influence of Education Level and Transformational Leadership on Career Development of Police Personnel in West Sumatera. 64, 800-806. https://doi.org/10.2991/piceeba2-18.2019.68

[52] Yuwono, T., Wiyono, N., Asbari, M., Novitasari, D., \& Silitonga, N. (2020). Analisis Pengaruh Efektivitas Kepemimpinan Transformasional dan Kesiapan untuk Berubah terhadap Kinerja Karyawan Wanita di Masa Pandemi Covid-19. Jurnal Ilmiah Mahasiswa Ekonomi Manajemen, 5(3), 615-632. http://www.jim.unsyiah.ac.id/EKM/article/view/15502

[53] Zurnali, C., \& Nadeak, W. (2010). Learning organization, competency, organizational commitment, and customer orientation: knowledge worker: kerangka riset manajemen sumber daya manusia masa depan. Unpad Press. 